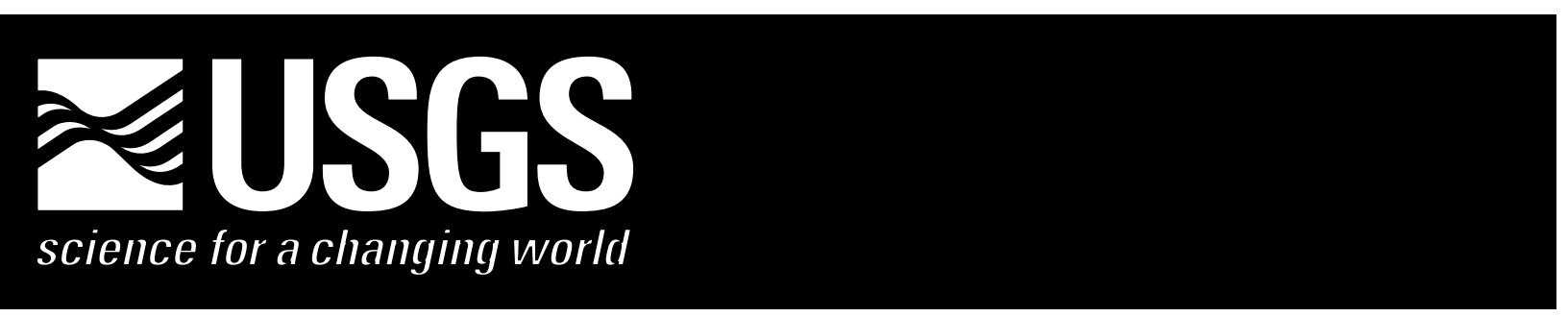

\title{
PUBLICATIONS OF THE WESTERN \\ EARTH SURFACE PROCESSES TEAM 1999
}

Compiled by Paul Stone ${ }^{1}$ and Charles L. Powell, ${ }^{1}{ }^{1}$

Open-File Report 00-215

2000

This report is preliminary and has not been reviewed for conformity with U.S. Geological Survey editorial standards or with the North American Stratigraphic Code. Any use of trade, firm, or product names is for descriptive purposes only and does not imply endorsement by the U.S. Government.

\section{U. S. DEPARTMENT OF THE INTERIOR \\ U. S. GEOLOGICAL SURVEY}

${ }^{1}$ U. S. Geological Survey, 345 Middlefield Road, Menlo Park, CA 94025 


\section{INTRODUCTION}

The Western Earth Surfaces Processes Team (WESPT) of the U.S. Geological Survey, Geologic Division (USGS, GD), conducts geologic mapping and related topical earthscience studies in the western United States. This work is focused on areas where modern geologic maps and associated earth-science data are needed to address key societal and environmental issues such as ground-water quality, potential geologic hazards, and land-use decisions. Areas of primary emphasis currently include southern California, the San Francisco Bay region, and the Pacific Northwest. The team has its headquarters in Menlo Park, California, and maintains field offices at several other locations in the western United States.

The results of research conducted by the WESPT are released to the public as a variety of databases, maps, text reports, and abstracts, both through the internal publication system of the USGS and in diverse external publications such as scientific journals and books. This report lists publications of the WESPT released in 1999 as well as additional 1997 and 1998 publications that were not included in the previous list (USGS Open-file Report 99-302). Most of the publications listed were authored or coauthored by WESPT staff. The list also includes some publications authored by non-USGS cooperators with the WESPT, as well as some authored by USGS staff outside the WESPT in cooperation with WESPT projects.

Several of the publications listed are available on the World Wide Web; for these, URL addresses are provided. Many of these Web publications are USGS open-file reports that contain large digital databases of geologic map and related information. For some of these, the bibliographic citation refers to an explanatory pamphlet containing information about the content and accessibility of the database, not to the actual map or related information comprising the database itself.

Information on ordering USGS publications can be found on the World Wide Web at http://www-nmd.usgs.gov/esic/to_order.html, or by calling 1-800-HELP-MAP. The U.S. Geological Survey's web server for geologic information in the western United States is located at http://geology.wr.usgs.gov.

\section{ADDITIONAL 1997 PUBLICATIONS}

Hereford, R., and Webb, R. H., 1997, How often does rain cause overland flow in the arid Mojave Desert? A study of reservoir deposits in Valjean Valley: San Bernardino County Museum Association Quarterly, v. 44, no. 1, p. 14.

Troost, K.G., Booth, D.B., Sarna-Wojcicki, A., Meyer, C.E., and Hagstrum, J.T., 1997, Chronology, mineralogy, and correlation of Quaternary tephra and mudflow deposits in the central Puget Lowland, Washington state [abs.]: Geological Society of America Abstracts with Programs, v. 29, no. 6, p. A-411-412. 


\section{ADDITIONAL 1998 PUBLICATIONS}

Jachens, R.C., Dixon, G.L., Langenheim, V.E., and Morin, R.L., 1998, Interpretation of an aeromagnetic survey over parts of the Virgin Valley, Tule Desert, and the valley surrounding Meadow Valley Wash, southeastern Nevada: U.S. Geological Survey Open-file Report 98-804, 16 p.

Langenheim, V.E. and Jachens, R.C., 1998, Structural framework of the Las Vegas Valley, Nevada, as determined by gravity and aeromagnetic data, in dePolo, C.M., ed., Seismic hazards in the Las Vegas region: Nevada Bureau of Mines and Geology Open-file Report 98-6, p. 161-180.

Mankinen, E.A., Hildenbrand, T.G., Roberts, T.G., and Davidson, J.G., 1998, Principal facts for new gravity stations in the Pahute Mesa and Oasis Valley area, Nye County, Nevada: U.S. Geological Survey Open-file Report 98-498, 14 p.

Naeser, N.D., Isaacs, C.M., and Keller, M.A., 1998, Regional thermal maturity of surface rocks, onshore Santa Maria Basin and Santa Barbara-Ventura Basin area, California, chap. X of Keller, M.A., ed., Evolution of sedimentary basins/onshore oil and gas investigations-Santa Maria Province: U.S. Geological Survey Bulletin 1995, p. X1-X31.

Rowan, E.L., Bird, K.J., Hayba, D.O., Choueiri, W., Wendebourg, J., and Rudkiewicz, J.L., 1998, Hydrogeologic factors affecting oil migration in the Canning River region, eastern North Slope, Alaska [abs.]: Eos, Transactions, American Geophysical Union, v. 79 , v. 45, supplement, p. F845.

Toro, J., Cole, F., and Meier, J.M., 1998, ${ }^{40} \mathrm{Ar} /{ }^{39} \mathrm{Ar}$ ages of detrital minerals in Lower Cretaceous rocks of the Okpikruak Formation: evidence for upper Paleozoic metamorphic rocks in the Koyukuk arc, in Gray, J.E. and Riehle, J.R., eds., Geologic studies in Alaska by the U.S. Geological Survey, 1996: U.S. Geological Survey Professional Paper 1995, p. 169-182.

Wahl, A.D., 1998, Cenozoic deformation of the Franciscan Complex, eastern Santa Maria Basin, California, chap. W of Keller, M.A., ed., Evolution of sedimentary basins/onshore oil and gas investigations-Santa Maria Province: U. S. Geological Survey Bulletin 1995, p. W1-W20.

\section{PUBLICATIONS}

Anderson, M.L., Jachens, R., and Woolfenden, L., 1999, Structural model of the San Bernardino strike-slip basin, southern California, from regional gravity data [abs.]: Eos, Transactions, American Geophysical Union, v. 80, no. 46, supplement, p. F1002. 
Bedford, D.R., and Miller, D.M., 1999, Digital resource database for management decisions in City of Rocks National Reserve, in Soller, D.R., ed., Digital mapping techniques '99-workshop proceedings: U.S. Geological Survey Open-file Report 99-386, p. 139-143, http://pubs.usgs.gov/openfile/of99-386.

Bedford, D.R., Miller, D.M., Yount, J.C., and Phelps, G.A., 1999, Modeling landscape vulnerability and recoverability in the Mojave Desert Ecosystem: granite-dominated sediments of the Kelso area [abs.]: Geological Society of America Abstracts with Programs, v. 31, no. 7, p. A-223.

Billingsley, G.H., 1999, Erosional surfaces of the Surprise Canyon Formation, chap. D of Billingsley, G.H. and Beus, S.S., eds., Geology of the Surprise Canyon Formation of the Grand Canyon, Arizona: Flagstaff, Ariz., Museum of Northern Arizona Bulletin 61, p. $53-68$.

Billingsley, G.H., 1999, Paleovalleys of the Surprise Canyon Formation in Grand Canyon, chap. C of Billingsley, G.H. and Beus, S.S., eds., Geology of the Surprise Canyon Formation of the Grand Canyon, Arizona: Flagstaff, Ariz., Museum of Northern Arizona Bulletin 61, p. 17-52.

Billingsley, G.H., and Beus, S.S., eds., 1999, Geology of the Surprise Canyon Formation, Grand Canyon, Arizona: Flagstaff, Ariz., Museum of Northern Arizona Bulletin 61, $254 \mathrm{p}$.

Billingsley, G.H., and Beus, S.S., 1999, Overview of the Surprise Canyon Formation, chap. A of Billingsley, G.H. and Beus, S.S., eds., Geology of the Surprise Canyon Formation of the Grand Canyon, Arizona: Flagstaff, Ariz., Museum of Northern Arizona Bulletin 61, p. 1-8.

Billingsley, G.H., Beus, S.S., and Grover, P., 1999, Stratigraphy of the Surprise Canyon Formation, chap. B of Billingsley, G.H. and Beus, S.S., eds., Geology of the Surprise Canyon Formation of the Grand Canyon, Arizona: Flagstaff, Ariz., Museum of Northern Arizona Bulletin 61, p. 9-16.

Billingsley, G.H., and Hampton, H.M., 1999, Physiographic rim of the Grand Canyon, Arizona: a digital database: U.S. Geological Survey Open-file Report 99-30, 10 p., scale 1:250,000, http://wrgis.wr.usgs.gov/open-file/of99-30.

Billingsley, G.H., Wenrich, K.J., Huntoon, P.W., and Young, R.A., 1999, Breccia-pipe and geologic map of the southwestern part of the Hualapai Indian Reservation and vicinity, Arizona: U.S. Geological Survey Miscellaneous Investigations Series Map I2554, scale 1:48,000.

Bird, K.J., 1999, Assessment overview, chap. AO in ANWR Assessment Team, ed., The oil and gas resource potential of the Arctic National Wildlife Refuge 1002 Area, Alaska: U.S. Geological Survey Open-file Report 98-34 (CD ROM). 
Bird, K.J., 1999, Geographic and geologic setting, chap. GG in ANWR Assessment Team, ed., The oil and gas resource potential of the Arctic National Wildlife Refuge 1002 Area, Alaska: U.S. Geological Survey Open-file Report 98-34 (CD ROM).

Bird, K.J., Burruss, R.C., and Pawlewiez, M.J., 1999, Thermal maturity, chap. VR in ANWR Assessment Team, ed., The oil and gas resource potential of the Arctic National Wildlife Refuge 1002 Area, Alaska: U.S. Geological Survey Open-file Report 98-34 (CD ROM).

Blakely, R.J., Jachens, R.C., Calzia, J.P., and Langenheim, V.E., 1999, Cenozoic basins of the Death Valley extended terrane as reflected in regional scale gravity anomalies, in Wright, L.A., and Troxel, B.W., eds., Cenozoic basins of the Death Valley Region: Geological Society of America Special Paper 333, p. 1-16.

Blakely, R.J., Morin, R.L., and Faunt, C.C., 1999, Looking beneath the surface, a threedimensional geophysical view of the Death Valley region, California and Nevada, in Slate, J.L., ed., Proceedings of conference on status of geologic research and mapping, Death Valley National Park: U.S. Geological Survey Open-file Report 99153 , p. $47-51$.

Blakely, R.J., Parsons, T.E., Brocher, T.M., Langenheim, V.E., and Ten Brink, U., 1999, A three-dimensional view of the Seattle basin, Washington, from gravity inversion and seismic velocity [abs.]: Eos, Transactions, American Geophysical Union, v. 80, no. 46, supplement, p. F762.

Blakely, R.J., Wells, R.E., and Weaver, C.S., 1999, Puget Sound aeromagnetic maps and data: U.S. Geological Survey Open-file Report 99-514, scale 1:100,000, http://geopubs.wr.usgs.gov/open-file/of99-514.

Blakely, R.J., Wells, R.E., Weaver, C.S., and Johnson, S.Y., 1999, Tectonic setting and earthquake hazards of the Seattle fault, Washington: implications from highresolution aeromagnetic data [abs.]: Seismological Society of America, Seismological Research Letters, v. 70, no. 2, p. 219.

Brabb, E.E., Colgan, J.P., and Best, T.C., 1999, Map showing inventory and regional susceptibility for Holocene debris flows and related fast moving landslides in the conterminous United States: U.S. Geological Survey Miscellaneous Field Studies Map MF-2329, on-line version 1.0, scale 1:2,500,000, http://geopubs.wr.usgs.gov/map-mf/mf2329.

Campbell, R.H., and Chirico, P.G, 1999, Geographic information system (GIS) procedure for preliminary delineation of debris-flow hazard areas from a digital terrain model, Madison County, Virginia: U.S. Geological Survey Open-File Report 99-336, $25 \mathrm{p}$. 
Castle, R.O., 1999, Work in progress: a connection through the brittle crust between Death Valley and the Salton Sea, in Slate, J.L., ed., Proceedings of conference on status of geologic research and mapping, Death Valley National Park: U.S. Geological Survey Open-file Report 99-153, p. 163-164.

Clague, D.A., Hagstrum, J.T., Champion, D.E., and Beeson, M.H., 1999, Kilauea summit overflows: their ages and distribution in the Puna District, Hawaii: Bulletin of Volcanology, v. 61, p. 363-381.

Cole, F., Bird, K.J., Mull, C.G., Wallace, W.K., Murphy, J.M., and Sassi, W., 1999, A balanced cross section and a kinematic and thermal model of the northeastern salient of the Brooks Range, Arctic National Wildlife Refuge, Alaska, in ANWR Assessment Team, ed., The oil and gas resource potential of the Arctic National Wildlife Refuge 1002 Area, Alaska: U.S. Geological Survey Open-file Report 98-34 (CD ROM).

Davidson, J.G., Berg, M.J., and Hamilton, J.C., 1999, Principal facts for 300 gravity stations in the vicinity of Los Angeles and Hollywood, California: U.S. Geological Survey Open-file Report 99-577, 14 p.

Davidson, J.G., Ponti, D.J., and Hildenbrand, T.G., 1999, Gravity and magnetic interpretation of the northern Los Angeles basin, implications for formation of the Hollywood basin [abs.]: Eos, Transactions, American Geophysical Union, v. 80, no. 46, supplement, p. F1003.

Evans, K.R., 1999, Sea-level changes during the late Cambrian Pterocephaliid biomere redux [abs.]: Geological Society of America Abstracts with Programs, v. 31, no. 6, p. A-53.

Evarts, R.C., Coleman, R.G., and Schiffman, P., 1999, The Del Puerto ophiolite: petrology and tectonic setting, in Wagner, D.L., and Graham, S.A., eds., Geologic field trips in northern California, centennial meeting of the Cordilleran section of the Geological Society of America: California Division of Mines and Geology Special Publication 119, p. 136-149.

Fridrich, C.J., Minor, S.A., and Mankinen, E.A., 1999, Geologic evaluation of the Oasis Valley basin, Nye County, Nevada: U.S. Geological Survey Open-file Report 99533-A, $55 \mathrm{p}$.

Gautier, D.L., and Wilson, R.C., 1999, Landslides and this year's precipitation in the San Francisco Bay area [abs.], in Wilson, R., and Buffaloe, L., eds., Proceedings of the fifteenth annual Pacific Climate (PACLIM) Workshop: Interagency Ecological Program for the Sacramento-San Joaquin Estuary, Technical Report 64, p. 130.

Graymer, R.W., Brabb, E.E., and Jones, D.L., 1999, Geology of the Cordelia and the northern part of the Benicia 7.5 minute quadrangles, California: a digital database: 
U. S. Geological Survey Open-file Report 99-162, 12 p., scale 1:24,000, http://wrgis.wr.usgs.gov/open-file/of99-162.

Hagstrum, J.T., Swanson, D.A., and Evarts, R.C., 1999, Paleomagnetism of an eastwest transect across the Cascade arc in southern Washington: implications for regional tectonism: Journal of Geophysical Research, v. 104, no. B6, p. 12,85312,864 .

Haugerud, R.A., 1999, The North American Cordillera: a color shaded-relief map in oblique Mercator projection about the Pacific-North America pole of rotation, scale circa 1:5,000,000: U.S. Geological Survey Open-file Report 98-140, http://wrgis.wr.usgs.gov/open-file/of98-140.

Hildenbrand, T.G., Langenheim, V.E., Mankinen, E.A., and McKee, E.H., 1999, Inversion of gravity data to define the pre-Tertiary surface and regional structures possibly influencing ground-water flow in the Pahute Mesa-Oasis Valley region, Nye County, Nevada: U. S. Geological Survey Open-file Report 99-49, 29 p., http://geopubs.wr.usgs.gov/open-file/of99-49.

Hillhouse, J.W., and Wells, R.E., 1999, Paleomagnetism of Miocene volcanic rocks in the Newberry Moutains, California: vertical-axis rotation and a polarity transition [abs.]: Eos, Transactions, American Geophysical Union, v. 80, no. 46, supplement, p. F286.

Howard, K.A., 1999, Neotectonics or paleofloods? Sorting the evidence in examples from the Colorado and Columbia Rivers [abs.], in House, P.K., ed., The second international paleoflood conference: Prescott, Ariz., p. 21.

Howell, D.G., Brabb, E.E., and Ahmad, R., 1999, Interest in landslide hazard information-parallels between Kingston, Jamaica and the San Francisco Bay region, USA, in Griffiths, J.S., Stokes, M.R., and Thomas, R.G., eds., Landslides: proceedings of the ninth international conference and field trip on landslides, Bristol, United Kingdom, 5-16 September 1999: Rotherdam, A.A. Balkema, p. 73-79.

Howell, D.G., Brabb, E.E., Pike, R.J., Ramsey, D.W., Roberts, S., and Hillhouse, J.W., 1999, Landslide hazard information and the decision-making process [abs.]: Geological Society of America Abstracts with Programs, v. 31, no. 6, p. A-64.

Howell, D.G., Brabb, E.E., and Ramsey, D.W., 1999, How useful is landslide information? Lessons learned in the San Francisco Bay region: International Geology Review, v. 41, no. 4, p. 368-381.

Howell, D.G., and Swinchatt, J.P., 1999, A discussion of geology, soils, wines, and history of the Napa Valley region, in Wagner, D.L., and Graham, S.A., eds., Geologic field trips in northern California, centenial meeting of the Cordilleran section of the 
Geological Society of America: California Division of Mines and Geology Special Publication 119, p. 80-88.

Howell, D.G., Swinchatt, J.P., and Vigil, J.F., 1999, Animations for petroleum systems:

U.S. Geological Survey Open-file Report 99-21 (CD-ROM).

Irwin, W.P., and Wooden, J.L., 1999, Plutons and accretionary episodes of the Klamath Mountains, California and Oregon: U.S. Geological Survey Open-file Report 99-374, 1 plate, http://wrgis.wr.usgs.gov/open-file/of99-374.

Isaacs, C.M., Keller, M.A., and Bird, K.J., 1999, Potentially hazardous trace elements in the Monterey Formation, California [abs.]: American Association of Petroleum Geologists Bulletin, v. 83, no. 4, p. 691.

Jachens, R.C., and Griscom, A., 1999, Middle and upper crustal geologic setting of the 1989 Loma Prieta, California, earthquake, inferred from magnetic and gravity anomalies [abs.]: Eos, Transactions, American Geophysical Union, v. 80, no. 46, supplement, p. F39.

Jachens, R.C. and Zoback, M.L., 1999, The San Andreas fault in the San Francisco Bay region, California: structure and kinematics of a young plate boundary: International Geology Review, 41, p. 191-205.

Jayko, A.S., and Pritchett, W.D., 1999, Estimate of late Quaternary denudation rate, Death Valley area, eastern California [abs.]: Eos, Transactions, American Geophysical Union, v. 80 , no. 46, supplement, p. F443.

Johnsson, M., Evans, K.R., and Marshall, H.A., 1999, Thermal maturity of sedimentary rocks in Alaska: digital resources: U.S. Geological Survey Digital Data Series, DDS-54 (CD-ROM).

Keller, M.A., Bird, K.J., and Evans, K.R., 1999, Petroleum source rock evaluation based on sonic and resistivity logs, in ANWR Assessment Team, ed., The oil and gas resource potential of the Arctic National Wildlife Refuge 1002 Area, Alaska: U.S. Geological Survey Open-file Report 98-34 (CD ROM).

Kennedy, S.A. and Matti, J.C., 1999, Data-base model specifications for digital geologic-map data-bases produced by the Southern California Aerial Mapping Project (SCAMP), version 2.0: U.S. Geological Survey Open-file Report 99-145, 47 p.

Knott, J.R., Sarna-Wojcicki, A.M., Klinger, R.E., Tinsley, J.C., III, and Troxel, B.W., 1999, Late Cenozoic tephrochronology of Death Valley, California: new insights into stratigraphy and tectonics, in Slate, J.L., ed., Proceedings of conference on status of geologic research and mapping, Death Valley National Park: U.S. Geological Survey Open-file Report 99-153, p. 115-116. 
Langenheim, V.E., 1999, Gravity and magnetic models along the Los Angeles region seismic experiment (LARSE Line 1), California: U.S. Geological Survey Open-file Report 99-388, 22 p.

Langenheim, V.E., Davidson, J.G., Anderson, M.L., and Blank, H.R., Jr., 1999, Principal facts for gravity stations and physical property measurements in the Lake Mead 30' by 60 ' quadrangle, Nevada and Arizona: U.S. Geological Survey Open-file Report 99-435, 15 p., http://geopubs.wr.usgs.gov/open-file/of99-435.

Langenheim, V.E., and Fuis, G.S., 1999, Constraints from gravity and aeromagnetic data on interpretation of the LARSE I seismic-refraction transect, southern California [abs.]: Eos, Transactions, American Geophysical Union, v. 80, no. 46, supplement, p. F1002.

Langenheim, V.E., Morin, R.L., Schmidt, K.M., Davidson, J.G., and Blank, H.R., Jr., 1999, Isostatic gravity map of the Las Vegas $30 \times 60$ minute quadrangle, Nevada and California: U.S. Geological Survey Open-file Report 99-398, scale 1:100,000, http://geopubs.wr.usgs.gov/open-file/of99-398.

Lapointe, P.A., Cook, H.E., Shirtliffe, N., and Dugravot, S., 1999, Upper Paleozoic mud mounds of the Bolshoi Karatau Mountains (Kazakstan), nature and reservoir Impact for North Caspian exploration [abs.]: American Association of Petroleum Geologists Annual Convention, Official Program, v. 8, p. A76-A77.

Liberty, L.M., Trehu, A.M., Blakely, R.J., and Dougherty, M.E., 1999, Integration of highresolution seismic and aeromagnetic data for earthquake hazards evaluations: an example from the Willamette Valley, Oregon: Seismological Society of America Bulletin, v. 89, no. 6 , p. 1473-1483.

Lillis, P.G., and Stanley, R.G., 1999, Petroleum systems of the La Honda basin, California [abs.]: American Association of Petroleum Geologists Bulletin, v. 83, no. 4, p. 694.

Macquaker, J.H.S., Keller, M.A., and Taylor, K.G., 1999, Sequence stratigraphic analysis of the lower part of the pebble shale unit, Canning River, northeastern Alaska, in ANWR Assessment Team, ed., The oil and gas resource potential of the Arctic Wildlife Refuge 1002 Area, Alaska: U.S. Geological Survey Open-file Report 98-34 (CD-ROM).

Magoon, L.B., Lillis, P.G., Bird, K.J., Burruss, R.C., Rowan, E., and Keller, M.A., 1999, The evaluation of hydrocarbon charge and timing using the petroleum system, in ANWR Assessment Team, ed., The oil and gas resource potential of the Arctic National Wildlife Refuge 1002 Area, Alaska: U.S. Geological Survey Open-file Report 98-34 (CD ROM). 
Magoon, L.B., Lorenson, T.D., McLaughlin, R.J., Stanley, R.G., Valin, Z.C., Lillis, P.G., Hodgson, S.F., Davisson, M. L., and Underwood, M.B., 1999, The geology and geochemistry of oil and gas seeps in California indicate up to tens of kilometers of petroleum migration [abs.]: American Association of Petroleum Geologists Bulletin, v. 83 , no. 4 , p. $695-696$.

Magoon, L.B., Lorenson, T.D., Valin, Z.C., Claypool, G.E., Warden, A., Lillis, P.G., Jenden, P.D., and Kaplan, I.R., 1999, Natural gas in the Great Valley of Californiacharacterization, origin, and petroleum systems [abs.], in Schoell, M., and Claypool, G.E., eds., Natural gas formation and occurrence: American Association of Petroleum Geologists Hedberg Conference, June 6-10, Durango, Colo., p. 1-2.

Mankinen, E.A., Hildenbrand, T.G., Dixon, G.L., McKee, E.H., Fridrich, C.J., and Laczniak, R.J., 1999, Gravity and magnetic studies of the Pahute Mesa and Oasis Valley region, Nye County, Nevada: U.S. Geological Survey Open-file Report 99303, $57 \mathrm{p}$.

Mankinen, E.A., Hildenbrand, T.G., Schenkel, C.J., and McKee, E.H., 1999, Geophysical assessment of subsurface structures possibly affecting ground-water flow west of the Nevada Test Site, southern Nevada [abs]: Eos, Transactions, American Geophysical Union, v. 80, no. 46, supplement, p. F327.

McDougall, K., Poore, R.Z., and Matti, J.C., 1999, Age and paleoenvironment of the Imperial Formation near San Gorgonio Pass, southern California: Journal of Foraminiferal Research, v. 29, no. 1, p. 4-25.

McKee, E.H., Hildenbrand, T.G., Anderson, M.L., Rowley, P.D., and Sawyer, D.A., 1999, The Silent Canyon Caldera Complex-a three-dimensional model based on drill-hole stratigraphy and gravity inversion: U.S. Geological Survey Open-file Report 99-555, 38 p., http://geopubs.wr.usgs.gov/open-file/of99-555.

McLaughlin, R.J., Clark, J.C., Jachens, R.C., Griscom, A., Langenheim, V.E., Schmidt, K.M., Wentworth, C.M., Wells, R.E., and Valin, Z.C., 1999, Geology and crustal structure of the Loma Prieta earthquake epicentral region [abs.]: Eos, Transactions, American Geophysical Union, v. 80, no. 46, supplement, p. F40.

McLaughlin, R.J., Langenheim, V.E., Schmidt, K.M., Jachens, R.C., Stanley, R.G., McDougall, K.A., Tinsley, J.C., and Valin, Z.C., 1999, Neogene contraction between the San Andreas fault and Santa Clara Valley, San Francisco Bay region, California: International Geology Review, v. 41, no. 1, p. 1-30.

McLaughlin, R.J., Sarna-Wojcicki, A., Fleck, R.J., Nilsen, T.H., Walker, J.P., Meyer, C.E., and Valin, Z.C., 1999, Initiation of active right-stepping dextral faults and implications for evolution of the San Andreas transform, northern San Francisco Bay region, California [abs.]: Eos, Transactions, American Geophysical Union, v. 80, no. 46, supplement, p. F735. 
McLaughlin, R.J., Stanley, R.C., Lillis, P.G., Magoon, L.B., Valin, Z.C., Underwood, M.B., Aalto, K.R., and Van de Kamp, P.C., 1999, Origin of petroleum, Neogene accretionary margin, Cape Mendocino-Eel River basin, northwestern California [abs.]: American Association of Petroleum Geologists Bulletin, v. 83, no. 4, p. 696.

Miller, D.M., and Bedford, D.R., 1999, Pluton intrusion styles, roof subsidence and stoping, and timing of extensional shear zones in the City of Rocks National Reserve, Albion Mountains, southern Idaho, in Spangler, L.E., and Allen, C.J., eds., Geology of northern Utah and vicinity: Utah Geological Association Publication 27, p. 11-25.

Miller, D.M., and Yount, J.C., 1999, Surficial geology and geomorphic process studies in support of multidisciplinary ecosystem investigations-examples from parts of Greenwater and Valjean Valleys, Mojave Desert Ecosystem, in Slate, J.L., ed., Proceedings of conference on status of geologic research and mapping in Death Valley National Park: U.S. Geological Survey Open-file Report 99-153, p. 113-114.

Miller, D.M., Yount, J.C., Phelps, G.A., and Bedford, D.R., 1999, Vulnerability and recoverability of the landscape in the Mojave Desert ecosystem-landscape mapping and physical response to disturbance [abs.]: Geological Society of America Abstracts with Programs, v. 31, no. 7, p. A-482.

Miller, F.K., Burmester, R.F., Miller, D.M., Powell, R.E., and Derkey, P.D., 1999, Digital geologic map of the Sandpoint 1- by 2-degree quadrangle, Washington, Idaho, and Montana: U.S. Geological Survey Open-file Report 99-144, 11 p., scale 1:250,000, http://geopubs.wr.usgs.gov/open-file/of99-144.

Miller, K.C., and Meltzer, A.S., 1999, Structure and tectonics of the offshore Santa Maria and Santa Lucia Basins, California: results from the PG\&E/EDGE seismic reflection survey, chap. Z of Keller, M.A., ed., Evolution of sedimentary basins/onshore oil and gas investigations-Santa Maria Province: U.S. Geological Survey Bulletin 1995, p. Z1-Z12.

Morin, R.L., Chuchel, B.A., and Blakely, R.J., 1999, Principal facts for about 500 gravity stations in the vicinity of Amargosa Desert and Pahrump Valley, California and Nevada: U.S. Geological Survey Open-file Report 99-31, 18 p.

Morton, D.M., Hauser, R.M., and Ruppert, K.R., 1999, Preliminary digital geologic map of the Santa Ana 30' x 60' quadrangle, southern California, version 1.0: U.S. Geological Survey Open-file Report 99-172, 15 p., http://wrgis.wr.usgs.gov/open-file/of99-172.

Nielson, J.E., and Bedford, D.R., 1999, Geologic map of the East of Grotto Hills quadrangle, California: a digital database: U.S. Geological Survey Open-file Report 99-35, 9 p., scale 1:24,000, http://wrgis.wr.usgs.gov/open-file/of99-35. 
Nielson, J.E., Turner, R.D., and Bedford, D.R., 1999, Geologic map of the Hart Peak quadrangle, California and Nevada: a digital database: U.S. Geological Survey Open-file Report 99-34, 9 p., scale 1:24,000, http://wrgis.wr.usgs.gov/open-file/of99-34.

Phelps, G.A., Langenheim, V.L., and Jachens, R.L., 1999, Thickness of Cenozoic deposits of Yucca Flat inferred from gravity data, Nevada Test Site, Nevada: U.S. Geological Survey Open-file Report 99-310, 33 p., http://wrgis.wr.usgs.gov/open-file/of99-310.

Phelps, G.A., and McKee, E.H., 1999, High-angle faults in the basement of Yucca Flats, Nevada Test Site, Nevada, based on analysis of a constrained gravity inversion surface: U.S. Geological Survey Open-file Report 99-383, 11 p., http://geopubs.wr.usgs.gov/open-file/of99-383.

Phelps, G.A., Miller, D.M., Yount, J.C., and Bedford, D.R., 1999, Modeling vulnerability and recoverability of the landscape at Valjean Valley, a pilot study area in the Mojave Desert ecosystem, based on surficial geologic mapping [abs.]: Geological Society of America Abstracts with Programs, v. 31, no. 7, p. A-223.

Pike, R. J., 1999, A bibliography of geomorphometry, the quantitative representation of topography—supplement 3.0: U.S. Geological Survey Open-file Report 99-140, 57 p.

Pike, R.J., 1999, Nano-metrology and terrain modeling—convergent practice in surface characterization [abs.]: TISD'99, Tribology of Information Storage Devices, University of Santa Clara, California, December 6-8, Abstract Book, p. 61.

Pike, R.J., and Graham, S.E., 1999, Digital maps of the San Francisco Bay region created in response to El Niño conditions forecast for the winter of 1997-98 [abs.]: $95^{\text {th }}$ Annual meeting, Association of American Geographers, Honolulu, Hawaii, March 23-27, AAG Newsletter, v. 34, no. 3, supplement, p. 474 (CD-ROM).

Pike, R.J., Graymer, R.W., and Roberts, S., 1999, GIS-based mapping of landslide susceptibility in the San Francisco Bay area, California [abs.]: Geological Society of America Abstracts with Programs, v. 31, no. 7, p. A-195.

Pike, R.J., Graymer, R.W., and Roberts, S., 1999, Regional modeling of landslide susceptibility in the San Francisco Bay region, California [abs.]: Eos, Transactions, American Geophysical Union, v. 80, no. 46, supplement, p. F450.

Ponce, D.A., 1999, Digital aeromagnetic map of the Nevada Test Site and vicinity, Nye, Lincoln, and Clark Counties, Nevada, and Inyo County, California: U.S.

Geological Survey Open-file Report 99-554-B, scale 1:120,000, http://greenwood.cr.usgs.gov/pub/open-file-reports/ofr-99-0554. 
Ponce, D.A., Mankinen, E.A., Davidson, J.G., Morin, R.L., and Blakely, R.J., 1999, Digital isostatic gravity map of the Nevada Test Site and vicinity, Nye, Lincoln, and Clark Counties, Nevada, and Inyo County, California: U.S. Geological Survey Openfile Report 99-554-C, scale 1:120,000, http://greenwood.cr.usgs.gov/pub/open-file-reports/ofr-99-0554.

Powell, C.L., II, 1999, Biostratigraphy of the "Purisima" Formation in the San Francisco Bay area, central California [abs.]: AAPG, SEPM, SEG, SPWLA, Pacific Section, Convention Program, p. 40.

Powell, C.L., II, and Stevens, D., 1999, Age and paleoenvironmental significance of mollusks from the "San Pedro" Formation, Coyote Hills, Orange County, southern California [abs.]: Western Society of Malacologists Abstract with Program, unnumbered page.

Powell, C.L., II, Ponti, D., and Lajoie, K., 1999, A preliminary chronostratigraphy for the late Quaternary of southern California based on molluscan biogeography [abs.]: Western Society of Malacologists Abstract with Program, unnumbered page.

Roberts, C.W., and Jachens, R.C., 1999, Preliminary aeromagnetic anomaly map of California: U.S. Geological Survey Open-file Report 99-440, 14 p., http://geopubs.wr.usgs.gov/open-file/of99-440.

Roberts, S., Roberts, M.A., Brennan, E.M., and Pike, R.J., 1999, Landslides in Alameda County, California, a digital database extracted from photointerpretation maps of surficial deposits by T.H. Nilsen in USGS Open-file Report 75-277: U.S. Geological Survey Open-file Report 99-504, 20 p., http://geopubs.wr.usgs.gov/open-file/of99-504.

Rowan, E.L., Anna, L.O., and Ridgley, J.L. , 1999, Effects of burial and groundwater flow history on the distribution of methane in Cretaceous reservoir rocks of northcentral Montana [abs.]: Geological Society of America Abstracts with Programs, v. 31, no. 7, p. A-353.

Schenkel, C.J., 1999, Magnetotelluric data in the Pahute Mesa and Oasis Valley areas, Nye County, Nevada: U.S. Geological Survey Open-file Report 98-504, 70 p.

Schenkel, C.J., Hildenbrand, T.G., and Dixon, G.L., 1999, Magnetotelluric study of Pahute Mesa and Oasis Valley region, Nye County, Nevada: U.S. Geological Survey Open-file Report 99-355, 39 p., http://geopubs.wr.usgs.gov/open-file/of99-355.

Schmidt, K.M., and Davidson, J.G., 1999, Using geomorphic features to constrain tectonic activity near Pahrump Valley, Nevada and California, in Slate, J.L., ed., 
Proceedings of conference on the status of geologic research and mapping, Death Valley National Park: U.S. Geological Survey Open-file Report 99-153, p. 154-155.

Snoke, A.W., Barnes, C.G., Lee, S.Y., and Howard, K.A., 1999, Emplacement, deformation, and exhumation of (29 Ma), sheet-like, monzogranitic intrusions in the Ruby Mountains core complex, northeastern Nevada [abs.]: Geological Society of America Abstracts with Programs, v. 31, no. 6, p. A-96.

Sorlien, C.C., Nicholson, C. and Luyendyk, B.P., 1999, Miocene extensional terranes and post-Miocene transpression in offshore south-central California, chap. Y of Keller, M.A., ed., Evolution of sedimentary basins/onshore oil and gas investigations-Santa Maria Province: U.S. Geological Survey Bulletin 1995, p. Y1Y38.

Stanley, R.G., 1999, Petroleum seep study, in Tuttle, M.L., and Breit, G.N., Environmental issues associated with fossil fuel resources-an evaluation of research opportunities for the U.S. Geological Survey's Energy Resources Program: U.S. Geological Survey Open-File Report 99-590, p. 14-16.

Stanley, R.G., and Lillis, P.G., 1999, Geology and organic geochemistry of oils from Davenport and Point Reyes, California, and implications for right-lateral displacement along the San Gregorio and San Andreas faults [abs.]: Eos, Transactions, American Geophysical Union, v. 80, no. 46, supplement, p. F-1004.

Stanley, R.G. and Lillis, P.G., 1999, New organic geochemical results from surface occurrences of oil and potential source rocks of oil near Point Reyes, Marin County, California [abs.]: American Association of Petroleum Geologists Bulletin, v. 83, no. 4, p. 702.

Stevens, C.H., Stone, P., and Ritter, S., 1999, Stratigraphy and biostratigraphy of the Pennsylvanian-Lower Permian Keeler Canyon basin, east-central California [abs.]: International Conference on the Carboniferous-Permian, 14th, Programme with Abstracts, p. 142.

Stone, P., and Powell, C.L., II, 1999, Publications of the Western Geological Mapping Team 1997-1998: U. S. Geological Survey Open-file Report 99-302, 28 p., http://wrgis.wr.usgs.gov/open-file/of99-302.

Tabor, R.W., and Haugerud, R.A., 1999, Geology of the North Cascades: a mountain mosaic: Seattle, Wash., Mountaineers, 143 p.

Tolan, T.L., Beeson, M.H., and Wheeler, K.L., 1999, Geologic map of the Scotts Mills, Silverton, and Stayton Northeast 7.5' quadrangles, northwest Oregon: a digital database: U.S. Geological Survey Open-file Report 99-141, 11 p., scale 1:24,000, http://wrgis.wr.usgs.gov/open-file/of99-141. 
Underwood, M.B., Shelton, K.L., McLaughlin, R.J., Laughland, M.M., and Solomon, R.M., 1999, Middle Miocene paleotemperature anomalies within the Franciscan Complex of northern California: thermo-tectonic response near the Mendocino triple junction: Geological Society of America Bulletin, v. 111, no. 10, p. 1448-1467.

Weaver, C.S., Meagher, K., Blakely, R.J., and Wells, R.E., 1999, The June 231997 Bainbridge Island, Washington, earthquake: evidence that the Seattle fault is seismically active [abs.]: Seismological Society of America, Seismological Research Letters, v. 70, p. 219-220.

Wells, R.E., Weaver, C.S., and Blakely, R.J., 1999, Microplate motion and neotectonics of the Cascadia forearc [abs.]: Seismological Society of America, Seismological Research Letters, v. 70, no. 2, p. 209.

Wentworth, C.M., Blake, M.C., Jr., McLaughlin, R.J., and Graymer, R.W., 1999, Preliminary geologic map of the San Jose $30 \times 60$ minute quadrangle, California: a digital database: U.S. Geological Survey Open-file Report 98-795, 14 p., scale 1:100,000, http://wrgis.wr.usgs.gov/open-file/of98-795.

Wong, I.G., Pezzopane, S.K., and Blakely, R.J., 1999, A characterization of seismic sources in western Washington and northwestern Oregon [abs.]: Seismological Society of America, Seismological Research Letters, v. 70, no. 2, p. 221.

Wooden, J.L., Kistler, R.W., and Tosdal, R.M., 1999, Strontium, lead, and oxygen isotopic data for granitoid and volcanic rocks from the northern Great Basin and Sierra Nevada, California, Nevada, and Utah: U.S. Geological Survey Open-file Report 99-569, 20 p.

Zempolich, W.G., Cook, H.E., Zhemchuznikov, V.G., and Zorin, A., 1999, Stratigraphic architecture and diagenesis of middle to late Paleozoic reefs and mounds of the Bolshoi Karatau Mountains, Kazakhstan and the southern Urals, Russia: an example of biotic demise and recovery [abs.]: American Association of Petroleum Geologists Annual Convention, Official Program, v. 8, p. A158.

Zoback, M.L., Jachens, R.C., and Olson, J.A., 1999, Abrupt along-strike change in tectonic style: San Andreas fault zone, San Francisco Peninsula: Journal of Geophysical Research, v. 104, no. B5, p. 10,719-10,742. 